\title{
Religious Based Learning as a Form of Cultivating Character Values in Children with Special Needs at SDLB Jenangan, Ponorogo
}

\author{
Vivi Vellanita Wanda Damayanti ${ }^{1}$, Restiana Irniasari² \\ 'State Islamic Institute of Ponorogo, Indonesia \\ 2SMA Negeri 1 Plus KPG Nabire, Indonesia \\ 1vvellanita@gmail.com*; ${ }^{2}$ restiirnia@gmail.com
}

\begin{abstract}
The application of character education has been carried out in public schools for more than a decade. In character education, the divinity value became the first value that was crucially determined and applied. By pointing the divinity value it is expected that students could understand the values of morality and humanity. Not only in public schools but also in special needs schools, the value of religiosity was applied and is a major cornerstone in the learning process. In this qualitative study the religious values were applied in SDLB Jenangan, Ponorogo, would be discussed in detail. The purpose of this research was to explain the urgency of building the character value in children with special in the learning process. Data in this study were collected using observation, interview, and documentation. The results of this study showed that the learning process carried out in SDLB Jenangan, Ponorogo, represented a religion-based learning system. This religion-based education aimed to make the special need students being able to increase their selfconfidence and control. Further, it is expected that the student would have the ability to minimize their attitudes.
\end{abstract}

Keywords:

Character Values; Religious Based Learning; Disabilities Students

This is an open access article under the CC-BY-NC license.

\section{INTRODUCTION}

Facing the decentralization and globalization era, in which the degradation of morals may happen the education takes a rule as a fundamental and priority of the Indonesian government. To realize the good educational product, the national education must not only focus on the knowledge but also the character building of students. Law No 23 the year 2003 about National Education System states that the functions of the national education areas the students' abilities developer and creator based on the national characteristics and civilization. This statement is in a hand with the statement of Hidayati et al (2014) who states that the education is a deliberate and conscious effort in creating an atmosphere of the learning process so that learners can actively improve their potency to improve their spiritual strength, self-control, personality and noble character which is important not only for themselves but also when they interact with society. Therefore, it can be inferred that the education must go together with the character building, hence, that is called the character education.

The word "character", which generally means the moral and mental quality of someone, comes from Greek, "kharassein" means tools for marketing, to engrave and pointed stake. This word, then, is adopted by French "caractere" which in the 14th century is used in English "character" and the next is also adopted by Indonesian in the word of "karakter" 
that specifically can be inferred as nature, psychological trait, moral or manner that differentiates someone with other (Agung, 2011). John Dewey in Agboola and Tsai (2012) defines the character as the interpenetration of habits. For this reason, the educational character should not be taken lightly because it would have a foundational and everlasting effect on the children's future (Agboola and Tsai, 2012).

Lickona (2012) defines the character as the conscious effort to help someone to understand, care, and do the ethical values. To realize it, it is needed a set system of morality must be done comprehensively and continuously. Each of them is synergizing and cannot be separated from each other in developing someone's character, namely moral concept, moral attitude, and moral behavior. Besides, Buchori and Setyawatin (2015) state that the character education is more than a process of making someone understands whether something is right or wrong, but how someone able to internalizing those moral values in daily life.

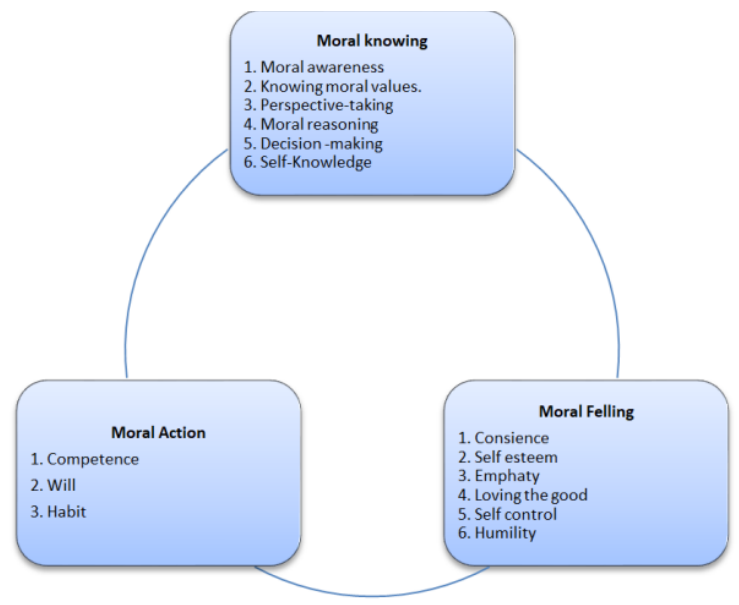

Figure 1. Lickona's Moral Values Cycle
The character education is a system that is created to cultivate students' character values, that can be used to be a whole and good human being who can serve the God, the own self, other humans, society, environment, and the nation (Mulyasa, 2011). The application itself was carried by the Indonesian government for more than a decade. This statement can be seen, implicitly, in the National Long-Term Development Plan (Rencana Pembangunan Jangka Panjang Nasional/ RPJPN) on 2005-2025 in which the Indonesian's government emphasized the emergence of character development at every educational level. Based on Kemendiknas or the Department of National Education (2010) those are eighteen characters that should be developed in the student's selves, namely: (1) religious, (2) honesty, (3) tolerance, (4) discipline, (5) work hard, (6) creative, (7) independent, (8) democratic, (9) curiosity, (10) spirit of nationality, (11) love the country, (12) rewarding achievement, (13) friendly/ communicative, (14) love of peace, (15) joy of reading, (16) environmental care, (17) social care, and (18) responsibility. Those eighteen values in 2016 are shortened into five main points: religiosity, nationalism, independence, cooperation, and integrity. 
(Kumalawati and Sormin, 2019, and Fathurrahman,

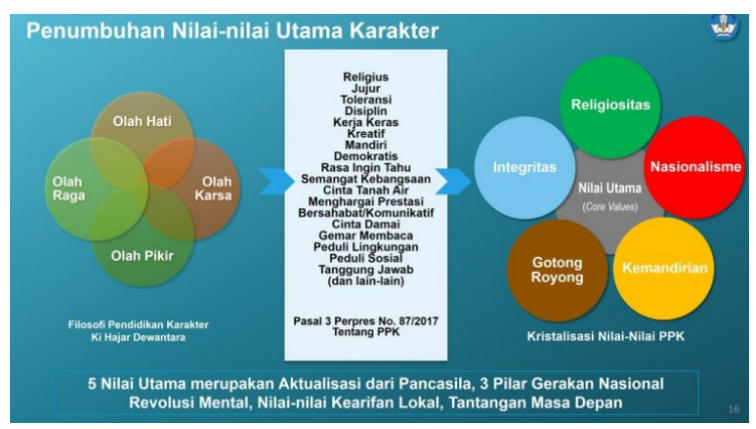

Picture 1. The Core of Character Values (source:https://cerdasberkarakter.kemdikbud.go.id/?

$$
\text { page_id=132) }
$$

Anwar et al., (2018) state that one of the guidance to strengthen and develop the character is by providing religious education. The religiosity becomes the first character of the eighteen character values that are mentioned by the Department of National Education. It is also becoming the main character of the core values that are published by the Ministry of Education and Culture. The religious education is needed and required in every type and level of education. The value of religiosity is applied and is a major cornerstone in the learning process (Asrori, 2016), not only in public schools but also in special needs schools or inclusive schools (Arsyad, 2014).

Khudrin (2012) states that the purposes of religious education in the teaching-learning process are to embody harmony between humans and God, humans with humans, and humans with nature. In the elementary school, the religious values are implemented to achieve the goals, those are: students can worship properly, students can read holly Koran, and students can get good morals
2014).

In the public schools, the values mentioned above can be taught by some method, such as: hiwar (conversation) of Qurani and Nabawi, the story of Qurani and Nabawi, amtsal of Qurani and Nabawi, exemplary of Qurani and Nabawi, habituation, "ibrah and mau'izah, and targhib and tarhib(Kumala and Sormin, 2019).

In this study, the religious value that is applied in SDLB Jenangan, Ponorogo, will be discussed in detail. The aim is to explain the urgency of building the character value in children with special needs.

\section{THEORETICAL PERSPECTIVES}

\section{Research Method}

This research is descriptive qualitative research that is conducted in the SDLB Jenangan, Ponorogo, East Java. A depth semi-structured interview is used to collect the data from the headmaster, two teachers, and 4 students' parents. Besides the interviewees, students in the third grade of SDLB Jenangan, consists of 3 males and a female (all of them have a mental delay) are choosing as the sample of this research. The reason for choosing this class as the sample of purposive sampling is because the students are aimed can serve the information. All of the students in this class are children with a mental disorder (down syndrome). This condition makes the students being a little hard to be taught by the usual method. The teacher decides to use religious-based learning as the approach to teaching educational values. For this 
reason, this class is aimed at research. Therewith the interview, the other data collection techniques used are observation and documentation. Those are chosen in purpose to make the data collected deeply and completely. Besides, the library research is also done to find the appropriateness of religion-based learning with the experts' theories.

In this research, the triangulation technique is used to verify the data. The data analyzing techniques include: data reduction, organizing/ processing the data, interpretation, and verification. To fulfill the reliability requirements, the checking is done by the prolongation observation, intra-rater, and checking the results with the experts' theories to see the appropriateness between the research and the theories.

\section{Religious Based Learning as the Part of Character}

\section{Building}

In character education, the divinity value becomes the first value that is crucially determined and applied. By pointing the divinity value, it is hoped that an educational output that will be formed, can understand the values of morality and humanity. The religious education is needed and required in every type and level of education. Anwar et al., (2018) state that one of the guidance to strengthen and develop the character is by providing religious education.

Mustafa and Salim (2012) state that religious education is important because through it, the character building of someone as a worshipper, as an individual, and also as the part of society that can be developed. Mustafa and Salim (2012) also define that religious education as an educational system in which the training of sensibility of students in such a manner -that in their attitude to life, their actions and decisions- and approach to all kinds of knowledge, are governed by the deep feeling of ethical values of goodness.

To make the students able to be kind, the religious point of view takes a role as an important thing to be applied consistently. It is in a hand with the Lickona's opinion (2012) that is the good character content is all about the kindness and good moral deeds. In short, to make students can have a religious character, the students must understand what the religion is, how to give attitude toward it, and how to apply it in their daily life continuously and consistently. The process of getting character is by making the children aware of the values, how to respond to it, and how to apply it in their daily life. The cycle of the character-building is shown below.

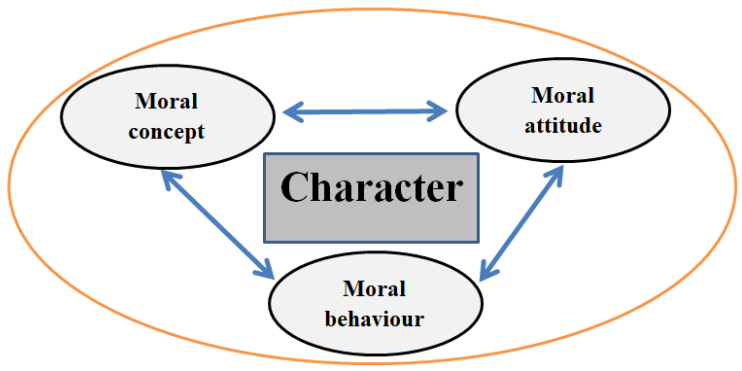

Figure 2. The Cycle of Character Building

The first thing to apply religious-based learning is to make students understand what religion is. It is related to how to give a moral concept to the students. In the SDLB Jenangan, Ponorogo, the students with a mental disorder are not given the 
concept of God in deep and detailed explanation. However, every single thing that is done by the students will be connected to the existence of God. For example, when students start to get their tantrum, such as crying loudly, being naughty, disturbing others, or being impolite, the teacher will remind them that God does not like them to act like that, so that humans. They must be kind. The other example is when they do a teaching-learning process that uses cultural sources, the teacher always reminds them that everything that exists in this world is created by God, and so on. The process of planting religious value without giving the students a deep and detailed concept is chosen by the teacher by the consideration that students will only confused if they have to understand some abstract concepts of God. This, by the statements of Kumalasari and Sormin (2019) that the special needs students with a mental disorder have low intelligence that makes them hard to receive an academic education, especially something that only is given in concept.

The second, to apply religious-based learning needs to make students aware. This is the part of how to make the students have an attitude in line with religion taught. In the public schools, to make students aware, it can be taught by some method, such as: hiwar (conversation) of Qurani and Nabawi, the story of Qurani and Nabawi, amtsal of Qurani and Nabawi, exemplary of Qurani and Nabawi, habituation, 'ibrah and mau'izah, and targhib and tarhib (Kumala and Sormin, 2019). However, in the special needs school with mental disorder students, the method that is possibly the most to be applied is by habituation. This also becomes the method that is applied in SDLB Jenangan to make the students achieve the third step of applying religious-based learning, that is applying the religious values in their daily life consistently and continuously.

The habitual can be applied by doing some activities that make children actively play and participate in the learning process (Novitawati et al, 2019) continuously and consistently. In the SDLB Jenangan, the activities are planned systematically. Regularly, children are stimulated to always greet others, kiss the teacher's hand, doing daily prayer (Dhuha and Dhuhur) together in the school, reciting the thoyibah sentence by song, reading daily prayers such as the prayer to learn, prayer

to eat, prayer in and out of the bathroom, and memorization of short surahs. They are also thaught to mentioning Asmaul Husna. These activities are done day by day, consistently and regularly, in purpose to create pleasant religious and moral learning situations for children and plant it as the students' habit.

\section{Religious Based Learning for the SDLB Students}

Special needs school or inclusive school is a school with disabilities students. Gal and Yeger (2010) define the disabilities students as the students who face obstacles due to their physical, emotional, and cognitive limitations. These limitations or barriers are within the individual and can be temporary or permanent. To handle this condition, the teachers are prepared to face and to 
find the special needs of individual children, including children with disabilities (Amini, 2017).

Holmberg and Jeyaprathaban (2016) state that some individuals based on their physical and mental abilities need instruction that is more appropriate or relevant than is usually available in the structure of the formal and informal educational system. These individuals are also known with the disabilities students (Hanum, 2014). On the other hand, the disabled person has been defined as 'a person with physical, intellectual, sensory or mental impairment and whose functional capacity is limited by facing attitudinal, environmental and institutional obstacles' (URT, 2010: 9). This definition is by Article 1 of the United Nations Convention on Persons with Disabilities in 2006 which describes persons with disabilities as those who have long-term physical, mental, intellectual or sensory impairments, which in interaction with various barriers can prevent them from fully and effectively participating in a society based on equality with others (Cosmas, 2018).

By taking into account the human rights perspectives, students with special needs must have access to equality in the education program. For this reason, inclusive education for children must be taken seriously, even to implement it, as several complex problems must be faced (Vramas, 2014). The problem arises to handle the special needs students may come in both human and cultural resources. The special need students need to learn in proper situations with the teacher that is expert in that field so that the ability of students can improve maximal. Hence, the inclusive education program is needed.

Inclusive education is an ongoing process that aims to offer quality education for all, while respecting differences and the different needs and abilities, characteristics and expectations of learning from students and society, eliminating all forms of discrimination (UNESCO in Vramas 2014). In Indonesia, inclusive school is also known as Special Need School (SLB or Sekolah Luar Biasa).

SLB Negeri Jenangan is a special need school that is oriented towards the skills and independence of the students. This school is an integrated school that includes 3 levels of education, namely Special Need Elementary School, Special Need Junior High School, and Special Need Senior High School. Based on the condition of the school and the students, the vocational skill is designed to increase the life skills of students with special needs through, in hope that the school will provide students with a vocational skill that is adjusted to the potential of each student so that one day students can be able to live during the community and have a skill that is accepted by the community. Not only providing the vocational skill, but SLB Jenangan also applied religious-based education to make the students able to be a religious human being with good character value inside them. For example, students will be able independently to do ablution and five daily prayers because they practice Dhuha and Dhuhur every day in the school. Students can do daily activity prayers before and after do something. They can act polite and be calmer, and soon. This, day by day, will be 
implemented as their habitual that conscious or unconsciously will build good character values inside mental disabilities or intellectual disabilities. Intellectual disability itself, also known as cognitive disability, previously called mental retardation, is described as a disability characterized by significant deficits both in intellectual functioning and in adaptive behavior as expressed in conceptual, social, and practical adaptive skills that occur before the age of 18 is where the need for support is a must (Tasse, Luckasson, \& Schalock, 2016). Moreover, Raty, Pirtimma, and Kontu (2016) state that it is important for the intellectual disabilities student to be taught by some approach that can promote physical activity and do it as their habit.

In the SDLB Jenangan, religious-based learning that promotes physical activity is done. The students will be placed in the variatif activities that need their body movements, such as doing prayers, singing Asmaul Husna, speak loudly the surahs, and others. Here, the students are guided to be active learners that do anything by themselves. Although it seems easy, it is hard to do. The teacher not only must be patient to guide the students but also must be a strong positive role. Teachers should be a good model for children and provide a good example for them.

The result of this study shows that the learning process carried out in SDLB Jenangan, Ponorogo, represented a religion-based learning system. The Focus of the research is in the third grade of students in the SDLB Jenangan consists of three males and a female. All of them have intellectual disabilities. Based on the interview and documentation, the application of religion-based education makes the special need students being able to increase their self-confidence and control. Some activities that are religiously oriented are applied, such as doing prays Dhuha and Dhuhur together, praying before doing anything, such as before learning, before eat and after learning. By doing this regularly, students will remember and apply it as their habit. When this goal is passed, the students' self-confidence will be improved. Through the interview with the teacher, it is known that the students who were able to do the activities designed would be more confident, not only in the school but also in their home. They are being braver to singing in front of others (some songs they already memorized), speak loudly when they are asked to pray the daily activity prayers, greet others (include someone they do not know yet), and so on. These positive attitudes show that religious-based learning successfully builds the self-confidence of the special needs students.

The punishment given to the special needs students in SDLB Jenangan who do some mistakes is not a physical punishment but by remembering some daily life prayers and some short surahs from the holy Quran. The purpose of applying these activities is to make the student being more behaving in both the school and their home. The students will remember when they do something wrong they have to memorize some things. They have not to be naughty, they should not disturb others, they must pay attention to the teacher and so on. If they do 
not, then they have to memorize some daily life prayers and some short surahs from the holy Quran.

This kind of punishment is chosen by the teacher because the teacher believes that the activities can make the students be more behaved and avoid them to act improperly. They also more regulate themselves in doing anything so that they are not be punished.

Religious based learning also makes the students being able to avoid themselves from the tantrum that often arises unpredictably on themselves. Special needs students type $C$ are often getting tantrum. It is a condition when they are angry, crying, screaming, raging, biting, hitting, scratching, or even hurting themselves (Rahmahtrisilvia, 2010, and Yosiani, 2014). In general, tantrum behavior can be classified as aggressive behavior done by a child to get out of deprivation condition (Syamsuddin, 2013). A tantrum can be solved by placing the students to activities that are varied and/ or move them from place to place. In the SDLB Jenangan, religiousbased learning that makes the students do not stick in one activity but move from activities to activities (such as, they are praying before learn, after that they coloring something like the main material, singing Asmaul Husna or memorizing the holy Quran surahs while clapping their hand, etc). They also move from place to place, such as from the classroom move to the small mosque (mushola), and then they can move to the garden (when the learning rest time). These, will avoid the students from deprivation conditions. Both the teachers and the parents agree that these activities can be a therapy to make the students behave well.

For the formal subject, the SDLB decides to not give them to many subjects but focus on the vocational subject. This, by considering the intellectual of the students, is purposed to make the students more focused and can optimally learn the applicative skill to make them being able to survive in the future. This decision was negotiated by the schools and parents and they agree to do this, together, for the students' future as what Wijayanti (2018) states that the goals of character education are to foster and strengthen the important values of life that need the cooperation of the school as the formal education, the families and the society as the place where the students live.

\section{CONCLUSION}

The result of this study shows that the learning process carried out in SDLB Jenangan, Ponorogo, represented a religion-based learning system. The subject of the research is in the third grade of students in the SDLB Jenangan, consist of three males and a female. All of them have intellectual disabilities. Based on the interview and documentation, the application of religion-based education makes the special need students being able to increase their self-confidence and control. They can be more behaving in both in the school and their home. They also more regulate themselves in doing anything. Religious based learning also makes them being able to avoid themselves from 
destructive attitudes that often arise unpredictably on themselves.

\section{REFERENCES}

Agboola, Alex., and Tsai, K. Chen. (2012). Bring

Character Education into the Classroom.

European Journal of Educational Research, vol 1(2), 163-170.

Agung, Leo. (2011). Character Education Integration

in Social Studies Learning. International Journal of History Education, vol 12 (2), 393.403.

Amini, Mukti. (2017). Implementation of Parenting

Education Program in Kindergarten. Indonesian Journal of Early Childhood Education Studies, vol 6(2), 113-119.

Anwar, Chairul., Saregar, A., Hasanah, U., and Widayanti. (2018). The Effectiveness of Islamic Religious Education in the Universities: The Effect on the Students' Characters in the Era of Industry 4.0. Tadris: Jurnal Keguruan dan IImu Tarbiyah, vol 3(1), 77-87.

Arsyad, A Rahman. (2014). Pendidikan Agama Pada Anak Berkebutuhan Khusus di SMPLB Sentra Pendidikan Khusus dan Pendidikan Layanan Khusus. Jurnal Al-Qalam, vol 20 (1), 161-170.

Asrori, Achmad. (2016). Contemporary Religious Education Model on the Challenge of Indonesian Multiculturalism. Journal of Indonesian Islam vol 10 (2), 261-283.

Buchori, Achmad., and Setyawati, R. Dwi. (2015). Development Learning Model of Character Education through E-Comic in Elementary School.
International Journal of Education and Research,vol 3(9), 369-386.

Cosmas, Juhudi. (2018). Educating Children with Intellectual Disabilities in Pre-Primary Education, Tanzania. International Journal of Education and Research, vol 6(7), 73-86.

Gal, Eynat., and Yeger, Batya Engel. (2010). Inclusion of Children with Disabilities: Teachers' Attitudes and Requirements for Environmental Accommodations. International Journal of Special Education, vol 25(2), 89-99.

Fathurrahman. (2014). Pembelajaran Agama pada Sekolah Luar Biasa. EL-HIKAM: Jurnal Pendidikan dan Kajian Keislaman, vol 7 (1), 67-92.

Hanum, Lathifah. (2014). Pembelajaran PAl bagi Anak Berrkebutuhan Khusus. Jurnal Pendidikan Agama Islam, vol 11 (2), 217-235.

Hidayati, Abna., Zaim. M., Rukun, K, and Darmansyah. (2014). The Development of Character Education Curriculum for Elementary Students in West Sumatera. International Journal of Education and Research, vol 2 (6), 199-198.

Holmberg, Jorun Buli., and Jeyaprathaban, Sujathamalini. (2016). Effective Practice in Inclusive and Special Needs Education. International Journal of Special Education, vol 31(1), 119-134.

Kementrian Pendidikan dan Kebudayaan. 2020). Kebijakan Penguatan Pendidikan Karakter. In https://cerdasberkarakter.kemdikbud.go.id/?pag e_id=132 accesed on 27th of April 2020. 
Kemendiknas. (2010). Pengembangan Pendidikan

Budaya dan Karakter Bangsa. Jakarta: Badan

Penelitian dan Pengembangan.

Khudrin, Ali. (2012). Pelaksanaan Pendidikan Agama Pada SDLB Asuhan Kasih Kota Kupang

Nusa Teggara Timur. Jurnal Analisa, vol 19 (1), 121-135.

Kumalasari, Intan and Sormin, Darliana. (2019).

Metode Pembelajaran Pendidikan Agama Islam pada Anak Tinagrahita di SLB C Muzdalifah Medan. Jurnal Penelitian IImu-ilmu Sosial dan Keislaman, vol 5 (1), 1-24.

Lickona, Thomas. (2012). Character Matters. Jakarta: Bumi Aksara

Mulyasa, E. (2011). Manajemen Pendidikan Karakter. Jakarta: Bumi Aksara.

Mustafa, Zaiton., and Salim, Hishamuddin. (2012). Factors Affecting Students' Interest in Learning Islamic Education. Journal of Educational and Practice, vol 3 (13), 81-86.

Novitawati., Ulfatin, Nurul., Arifin, Imron., And Aslamiah. (2019). Religious Scientific Learning Based on Sentra in School. International Journal of Innovation, Creativity and Change vol 5 (5), 190-203.

Rahmahtrisilvia. (2010). Strategi Pembelajaran untuk Mengatasi Perilaku Tantrum pada Anak Autistik. Pedagogi: Jurnal IImiah IImu Pendidikan, vol $10(2), 1-10)$

Raty, Lauri., Pirtimma, Raija., and Kontu, Eina. (2016). Teaching Children with Intellectual Disabilities: Analysis of Research-Based
Recommendation. Journal of Education and Learning, vol 5(2), 318-335.

Syamsuddin. (2013). Mengenal Perilaku Tantrum dan Bagaimana Mengatasinya. Informasi, vol 18 (2), 73-82.

Tassé, M. J., Luckasson, R. \& Schalock, R. L. (2016). The Relation between Intellectual Functioning and Adaptive Behavior in the Diagnosis of Intellectual Disability. Intellectual and Developmental Disabilities, vol 54 (6), 381-390. Vrasmas, Traian. (2014). Curriculum for Children with Disabilities in Inclusive Education: A Literature Review. Elsevier (Precedia-Social and Behavioral Science), vol 127, 336-341.

Wijayanti, Dwi. 2018. Character Education Designed by Ki Hajar Dewantara. Jurnal Pendidikan Dasar, vol. 10(2), 85-91.

Yosiani, Novita. (2014). Relasi Karakteristik Anak Tunagrahita dengan PolaTata Ruang Belajar di Sekolah Luar Biasa. E-Journal Graduate Unpar, vol 1 (2), 111-124. 